\title{
Alternative splicing generates a novel isoform of the rat metabotropic $\mathrm{GABA}_{\mathrm{B}} \mathrm{R} 1$ receptor
}

\author{
Torsten Pfaff, ${ }^{1}$ Barbara Malitschek, ${ }^{2}$ Klemens Kaupmann, ${ }^{2}$ Laurent Prézeau, ${ }^{3}$ Jean-Philippe Pin, ${ }^{3}$ Bernhard Bettler ${ }^{2}$ \\ and Andreas Karschin ${ }^{1}$ \\ ${ }^{1}$ Molecular Neurobiology of Signal Transduction, Max-Planck-Institute for Biophysical Chemistry, Am Fassberg 11,37070 \\ Göttingen, Germany \\ ${ }^{2}$ Novartis Pharma Inc., Therapeutic Area Nervous System, CH-4002 Basel, Switzerland \\ ${ }^{3}$ Mécanismes Moléculaires des Communications Cellulaires, CNRS-UPR9023, CCIPE, 34094 Montpellier, France
}

Keywords: alternative splicing, $\gamma$-aminobutyric acid, Kir3 channel, metabotropic receptors, synaptic inhibition

\begin{abstract}
Here we present a novel isoform of the metabotropic G-protein-coupled receptor for $\gamma$-aminobutyric acid (GABA). The isoform, termed $\mathrm{GABA}_{\mathrm{B}} \mathrm{R} 1 \mathrm{c}(\mathrm{R} 1 \mathrm{c})$, differs from the recently identified $\mathrm{R} 1 \mathrm{a}$ and $\mathrm{R} 1 \mathrm{~b}$ receptors by an in-frame insertion of 31 amino acids between the second extracellular loop and the fifth transmembrane region. Analysis of the rat $G A B A_{B} R 1$ gene demonstrates that the insertion is the result of an alternative splicing event within a 567-bp intron between exons 16 and 17 . In situ hybridization in the rat brain shows a wide distribution of R1c transcripts and an overlap with the R1a and R1b transcripts. The highest mRNA levels are found in cerebellar Purkinje cells, cerebral cortex, thalamus and hippocampal CA1 and CA3 regions. Western blots and immunodetection of recombinant epitope-tagged receptors as well as $\left[{ }^{125} \mathrm{I}\right]$ CGP71872 photoaffinity labelling of cell membranes demonstrate that R1c is correctly expressed, although at a lower level than the previously identified isoforms. When coexpressed with the newly characterized $\mathrm{GABA}_{\mathrm{B}} \mathrm{R} 2$, R1c functionally couples to G-protein-activated Kir3.1/3.2 channels in Xenopus oocytes and to PLC-activating chimeric Goqo subunits in HEK-293 cells with a similar $\mathrm{EC}_{50}$ for agonists. These data suggest that the R1c isoform represents a functional $\mathrm{GABA}_{\mathrm{B}} \mathrm{R}$ in the rat brain.
\end{abstract}

\section{Introduction}

The main inhibitory neurotransmitter in the mammalian central nervous system, $\gamma$-aminobutyric acid (GABA), targets two major types of receptors. $\mathrm{GABA}_{\mathrm{A}}$ receptors which mediate fast inhibition at central synapses were identified molecularly more than 10 years ago (Schofield etal., 1987). They are ligand-gated ion channels that conduct $\mathrm{Cl}^{-}$ions and are probably formed as pentameric structures from different subunits. Other pharmacologically distinct GABAgated $\mathrm{Cl}^{-}$channels have been termed $\mathrm{GABA}_{\mathrm{C}}$ receptors and are considered a subgroup of $\mathrm{GABA}_{\mathrm{A}}$ receptors (Johnston, 1996; Bowery \& Brown, 1997). In contrast, $\mathrm{GABA}_{\mathrm{B}}$ receptors are linked to $\mathrm{G}$ proteins, soluble cytoplasmic messengers, as well as $\mathrm{K}^{+}$and $\mathrm{Ca}^{2+}$ channels (Kerr \& Ong, 1995). Although abundantly expressed in the mammalian central nervous system, the molecular structure of $\mathrm{GABA}_{\mathrm{B}}$ receptors has remained elusive until recently. Numerous attempts to clone them, e.g. using functional expression in Xenopus laevis oocytes, failed to isolate the cDNA and reveal the primary amino acid sequence. Only last year an alternative approach proved successful. Using the high-affinity antagonist [ ${ }^{125}$ I]CGP64213 to detect heterologously expressed $\mathrm{GABA}_{\mathrm{B}} \mathrm{Rs}$ by radioligand binding, Kaupmann etal. (1997) isolated two $\mathrm{GABA}_{\mathrm{B}} \mathrm{R}$ variants, R1a and $\mathrm{R} 1 \mathrm{~b}$, which differed in their N-termini and coded for proteins of 960 and 844 amino acids, respectively. As expected, their molecular architecture revealed seven closely spaced $\alpha$-helical transmembrane

Correspondence: Dr Andreas Karschin, as above.

E-mail: akarsch@gwdg.de

Received 15 December 1998, revised 24 March 1999, accepted 7 April 1999 regions, indicative of G-protein-coupled receptors. From their primary sequence the $\mathrm{GABA}_{\mathrm{B}} \mathrm{Rs}$ are most closely related to members of the metabotropic glutamate receptor family mGluR (Nakanishi, 1994; Pin \& Duvoisin, 1995), the $\mathrm{Ca}^{2+}$-sensing receptor (Brown et al., 1993) and the vomeronasal receptors (Matsunami \& Buck, 1997; Bettler et al., 1998).

When investigated after transfection in COS-1 cells, the two variants R1a and R1b exhibited similar binding affinities for agonists and antagonists. Also, in HEK-293 cells both receptors mediated inhibition of adenylyl cyclase through PTX-sensitive G-proteins, but no functional coupling to intrinsic ionic conductances was reported in Xenopus oocytes. Both high- and low-affinity $\mathrm{GABA}_{\mathrm{B}}$ Rs have been described (Wojcik etal., 1990); receptors are located on pre- and postsynaptic sites (Bonanno \& Raiteri, 1993; Cunningham \& Enna, 1996), and receptors have been shown to connect to multiple cellular signal transduction pathways (Kerr \& Ong, 1995). In the present study we describe an additional $\mathrm{GABA}_{\mathrm{B}} \mathrm{R}$ splice variant, $\mathrm{GABA}_{\mathrm{B}} \mathrm{R} 1 \mathrm{c}$ (R1c), with a 31-amino-acid insertion. We demonstrate that R1c, when coexpressed with $\mathrm{GABA}_{\mathrm{B}} \mathrm{R} 2$, is targetted to the cellular membrane, functionally couples to downstream effectors and is widely expressed in the rat brain. Furthermore we present the complete genomic structure of the rat $G A B A_{B} R 1$ gene.

\section{Materials and methods}

\section{Molecular biology}

Primary hippocampal neurons $\left(\approx 4 \times 10^{4}\right)$ of male Wistar rats were used to construct a cDNA library in the oocyte transcription vector 
pSGEM (Pfaff \& Karschin, 1997). Total RNA was isolated using the guanidinium method and selective silica gel-based membrane binding (Rneasy, Qiagen, Hilden, Germany). Poly $\left(\mathrm{A}^{+}\right)$RNA was obtained after suspension with oligo(dT)-coupled latex particles (Oligotex, Qiagen). Nine directed EcoRI-XhoI cDNA sublibraries, each consisting of 10 size-selected plasmid fractions (1100-4500 bp), were constructed in pSGEM. Plasmids from $\approx 10^{5}$ colonies of each sublibrary were rescued (in total $\approx 9 \times 10^{5}$ independent clones) and the cDNA used as a template for further PCR analysis and in vitro transcription.

For analysis of the $G A B A_{B} R 1$ gene structure a rat genomic $\lambda$-phage library (DASH; Stratagene, La Jolla, CA, USA) was homologyscreened under high stringency conditions using three ${ }^{32} \mathrm{P}$-labelled DNA-probes obtained by PCR amplification of rat genomic DNA. Genomic DNA was isolated from $25 \mathrm{mg}$ of rat cortex by membrane adsorption and anion exchange using the QIAmp tissue isolation procedure (Qiagen). The DNA probes were selected to cover the regions of bases 585-902, 967-1248 and 1916-2340 of the rat R1a cDNA and were $3.5,1$ and $3.5 \mathrm{~kb}$, respectively, in length. Homology screening of $10^{6}$ clones resulted in the isolation of five positive clones between 9 and $12 \mathrm{~kb}$ in length, of which two covered the majority of the $G A B A_{B} R 1$ gene with the exception of the last $5^{\prime}$ end. The missing 183 bases at the $5^{\prime}$ end of the cDNA were obtained by PCRamplification of genomic DNA with the upper primer (5'ATGCTGCTGCTGCTGCTGGTGCCTCTCTTC-3') and lower primer (5'-CCTCGGCACACATATTCGATC-3'). For sequence analysis, gene fragments were PCR-amplified from both the genomic clones and total genomic DNA using specific primer combinations from the rat R1a and R1b cDNA sequences (Kaupmann et al., 1997) and taq polymerase (Qiagen). Reactions were performed with a hot start at $94{ }^{\circ} \mathrm{C}$ for $4 \mathrm{~min}$ (one cycle), $94{ }^{\circ} \mathrm{C}$ denaturing, $54-58^{\circ} \mathrm{C}$ annealing and $72{ }^{\circ} \mathrm{C}$ extension $(1 \mathrm{~min} / 1 \mathrm{~kb}, 33$ cycles $)$ and a final extension at $72{ }^{\circ} \mathrm{C}$ for $6 \mathrm{~min}$. Gel-eluted DNA of amplified fragments was subcloned or directly double-strand sequenced (30-90 ng) using the prism sequenase dye terminator kit on an automatic sequencer (Perkin Elmer, Weiterstadt, Germany). Sequences were analysed using National Center for Biotechnology Information databases and software from the Genetics Computer Group (Madison, WI, USA).

To verify the complete cDNA sequence of the PCR-amplified fragments that included the TM5 insertion, the cDNA of the R1c splice variant was isolated from a rat cortex library (Kaupmann et al., 1997). For this purpose a total of $2 \times 10^{6}$ clones were screened with a $\left[{ }^{32} \mathrm{P}\right]$-end-labelled 43-mer oligonucleotide from the TM5-insertion (5'-GGAGGGCCACTGTAGGCGGTGACTCACC-

CATCTGTGTCTGGCC-3') using standard conditions.

\section{Immunoblots and immunocytochemistry}

For Western blot and immunocytochemical analysis, the R1a and R1b variants with and without the 93-bp insertion were epitope-tagged at the cytoplasmic C-terminus with a 14-amino-acid peptide (ALAQAPPVYLDVLG) of the human NGF receptor (trkA). All constructs were inserted into the expression vector pcDNA3 (Invitrogen, NV Leek, Holland) and verified by DNA sequencing. For membrane preparations, COS-7 cells were grown on 100-mm Petri dishes to $30 \%$ confluency and transiently transfected with $15 \mu \mathrm{g}$ of each cDNA using calcium phosphate precipitation. After $72 \mathrm{~h}$, cells were harvested and membranes processed for SDS-polyacrylamide (10\%) gel electrophoresis as described (Wischmeyer et al., 1997). Proteins were transferred onto Immobilon-P PVDF membranes (Millipore, Bedford, MA, USA) using the wet transfer method. To reduce nonspecific binding, the blots were blocked with 5\% nonfat milk dissolved in TBS/Tween (20 mM Tris- $\mathrm{HCl}, \mathrm{pH} 7.4,15 \mathrm{~mm} \mathrm{NaCl}$,
$0.1 \%$ Tween 20) and then probed with rabbit $\alpha$-trkA antibodies (Santa Cruz Biotechnology, Santa Cruz, CA, USA). Immunoblots were developed using horseradish peroxidase-conjugated goat antirabbit immunoglobins (1:10000; Jackson ImmunoResearch, West Grove, PA, USA) and an enhanced chemoluminescence detection system (ECL, Amersham, Buckinghamshire, UK). For immunocytochemistry, transfected cells were fixed with $4 \%$ paraformaldehyde, washed with $0.1 \mathrm{M}$ PBS and pretreated for $30 \mathrm{~min}$ with $10 \%$ normal goat serum $/ 1 \%$ bovine serum albumin in $0.5 \%$ Triton-X-100. Following incubation in primary rabbit $\alpha$-trkA antibodies for $2 \mathrm{~h}$, specimens were washed and treated with $\mathrm{Cy} 3$-conjugated goat secondary antibody (Jackson ImmunoResearch Laboratories) for $2 \mathrm{~h}$, washed again and mounted under Mowiol 4-88 (Hoechst, Frankfurt, Germany). Slides were viewed with a $\times 63$ Plan Neofluar objective on a confocal Axiovert 135 TV microscope (Zeiss, Oberkochen, Germany) equipped with an argon-crypton laser (excitation lines at 488 and $568 \mathrm{~nm}$ ) and digitized images were stored and assembled using Adobe software (San Jose, CA, USA).

\section{In situ hybridizations}

Processing of 10-16- $\mu \mathrm{m}$ brain cryosections of adult Wistar rats and in situ hybridization analysis of $\mathrm{GABA}_{\mathrm{B}} \mathrm{R}$ transcripts followed the procedures outlined previously (Karschin etal., 1996). Synthetic antisense oligonucleotides were chosen from the insertion region (bases 5-56: 5'-GCCTACAGTGGCCCTCCGCTGAACATCACTACTCACAGCAAAAGACCAAAG- $\left.3^{\prime}\right)$ and the conserved 6th transmembrane domain of R1a $\left({ }^{2017} 5^{\prime}\right.$-CAGGGCCCTGTGGTCATTGATCTTTTCAGTGGACACGCTCTTGGTTTC-3'2064) and $3^{\prime}$-endlabelled with $\left[{ }^{33} \mathrm{P}\right]-$ or $\left[{ }^{35} \mathrm{~S}\right]-\mathrm{dATP}$ (New England Nuclear, Boston, MA, USA) by terminal deoxynucleotidyl transferase (TdT, Boehringer Mannheim, Mannheim, Germany). Controls used sense cDNA in adjacent sections, RNAse digestion prior to specific hybridization, and hybridization with a mixed probe containing a 100-fold excess of nonradioactive probe. After hybridization, specimens were dehydrated, air-dried and exposed to Biomax X-ray film (Kodak, Rochester, NY, USA) for 18 days.

\section{Photoaffinity crosslinking}

Membranes from transfected cells were prepared 3 days after

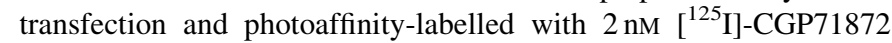
as described (Kaupmann et al., 1997). In control experiments, $1 \mu \mathrm{M}$ of the nonradioactive $\mathrm{GABA}_{\mathrm{B}} \mathrm{R}$ antagonist CGP54626 A was included.

\section{Electrophysiology}

Semiconfluent COS-7 and HEK-293 cells were cotransfected with $1 \mu \mathrm{g} / \mathrm{mL} \mathrm{GABA}_{\mathrm{B}} \mathrm{R}$ cDNA in pcDNA3 together with $0.5 \mu \mathrm{g}$ of concatemeric constructs from two Kir3 subunits (Wischmeyer et al., 1997) using LipofectAMINE and Opti-MEM I (Life Technologies, Gaithersburg, MD, USA) following the manufacturer's protocol. In brief, whole-cell recordings were performed at room temperature 48 $72 \mathrm{~h}$ post-transfection in a bath solution consisting of (in $\mathrm{mM}$ ): $\mathrm{NaCl}$, 135; $\mathrm{KCl}, 5.4 ; \mathrm{CaCl}_{2}, 1.8 ; \mathrm{MgCl}_{2}, 1$; glucose, $10 \mathrm{mM}$; and HEPES, 5, $\mathrm{pH}$ 7.4. Patch pipettes were pulled from borosilicate glass capillaries (Kimble Products, Sussex, UK) and heat-polished to give input resistances of 4-6 $\mathrm{M} \Omega$. The pipette recording solution contained (in $\mathrm{mM}$ ): $\mathrm{KCl}, 140 ; \mathrm{MgCl}_{2}$, 2; EGTA, 1; $\mathrm{Na}_{2} \mathrm{ATP}, 1$; cyclic AMP, 0.1; GTP, 0.1; and HEPES, 5, pH 7.3. Currents were recorded with an EPC9 patch clamp amplifier (Heka Electronics, Lambrecht, Germany) and low-pass filtered at $2.9 \mathrm{kHz}$. Stimulation and data acquisition were controlled with PULSE/PULSEFIT software (Heka). Series resistance of cells was compensated by $>80 \%$, resulting in a maximum voltage error of $1-2 \mathrm{mV}$. 
cRNA transcripts of R1b or R1c were coinjected into defolliculated Xenopus oocytes together with R2 and Kir3.1/Kir3.2 cRNA. Oocytes were incubated at $20^{\circ} \mathrm{C}$ in ND96 solution (in mM: $\mathrm{NaCl}, 96 ; \mathrm{KCl}, 2$; $\mathrm{MgCl}_{2}, 1 ; \mathrm{CaCl}_{2}, 1$; and HEPES, 5, pH 7.4) supplemented with $100 \mu \mathrm{g} / \mathrm{mL}$ gentamicin and $2.5 \mathrm{~mm}$ sodium pyruvate, and assayed 3 days after injection. Two-electrode voltage measurements were made with a two channel TURBO TEC-10 C amplifier (npi, Tamm, Germany) and sampled through an EPC9 interface as described above. Oocytes were placed in a small-volume perfusion chamber with a constant flow of $\mathrm{ND} 96$ or high $\mathrm{K}^{+}$solution (in $\mathrm{mM}$ : $\mathrm{KCl}, 96$; $\mathrm{NaCl}, 2 ; \mathrm{MgCl}_{2}, 1 ; \mathrm{CaCl}_{2}, 1$; and HEPES, 5, pH 7.4).

\section{Determination of inositol phosphate (IP) accumulation}

HEK-293 cells were cultured in Dulbecco's modified Eagle's medium (Gibco BRL, Cergy Pontoise, France) supplemented with $10 \%$ foetal calf serum and transfected by electroporation as previously described (Blahos II et al., 1998). Electroporation was carried out in a total volume of $300 \mu \mathrm{L}$ with $10 \mu \mathrm{g}$ carrier DNA, plasmid DNA containing R1a, R1b, R1c and R2 (1 $\mu \mathrm{g}$ each), and $5 \times 10^{5}$ cells. Chimeric Goqo protein subunits were coexpressed with R1/R2 to allow activation of PLC. Determination of IP accumulation in transfected cells was performed as previously described (Blahos II et al., 1998). In brief, HEK-293 cells were labelled overnight with $\left[{ }^{3} \mathrm{H}\right]$-myo-inositol $(23.4 \mathrm{Ci} / \mathrm{mol}, \mathrm{NEN}$, France). The basal IP formation was determined after 30 min incubation in the presence of $10 \mathrm{mM}$ LiCl. Stimulation by agonist was always conducted for the same period of time, and when antagonists were used they were added to the medium $5 \mathrm{~min}$ before agonists. The concentration of GABA used as agonist was $5 \mu \mathrm{M}$, close to the $\mathrm{EC}_{50}$ of GABA on $\mathrm{R} 1 / \mathrm{R} 2$ receptors, to get a full antagonist effect. Results are expressed as the amount of IP produced over the radioactivity present in the membranes.

\section{Results}

In a search for putative $\mathrm{GABA}_{\mathrm{B}} \mathrm{R}$ variants, a fractionated rat hippocampus cDNA library was used as template for PCR amplifications with $\mathrm{GABA}_{\mathrm{B}} \mathrm{R}$-specific primer combinations. Using this approach, an oligonucleotide primer pair expected to amplify a 425-bp fragment between TM2 and TM5 of the $\mathrm{GABA}_{\mathrm{B}} \mathrm{R}$ yielded an additional, slightly larger, fragment of $520 \mathrm{bp}$ in one of eight sublibraries (Fig. 1A). Further analysis revealed the presence of the larger fragment in a subdivision of this sublibrary $\left(\approx 10^{5}\right.$ independent clones). The relative abundance of this fragment in the sublibraries of both rat hippocampal and cerebellar (data not shown) cDNA libraries suggested that it was represented at low level (ratio of $\approx 4: 1$ ). This ratio is in accordance with the frequency of R1c clones in the rat brain library as estimated from homology screening (see below). Subcloning and sequencing demonstrated that the 425-bp fragment was identical to the equivalent region of the published rat $G_{A B A} R 1$ sequence (Kaupmann etal., 1997), whereas the larger fragment carried an insertion of an additional 93 nucleotides. Protein translation indicated that the in-frame insertion encoded 31 amino acids located between the second extracellular loop and TM5 (Fig. 1B). After submission of our manuscript, Isomoto et al. (1998) reported the isolation of a rat cDNA termed $\mathrm{GABA}_{B} \mathrm{R} 1 \mathrm{c}$ with an identical 31-amino-acid insertion. Database searches of both nucleotide and amino acid sequences of the insertion failed to detect significant similarities to other known sequences. The primary protein structure, however, suggested a loop structure with three short, alternating stretches of hydrophilic and hydrophobic residues, a motif that has been recognized before in a short, 29-amino-acid peptide insertion of alternatively spliced dopamine D2 receptors (Guiramand etal., 1995).

Homology screening of a rat cerebellar library using a 43-mer oligonucleotide within the TM5-insertion as a probe identified a total of 39 positive clones. When cDNAs were sequenced $5^{\prime}$ ends were identified that were identical in sequence to either R1a or R1b. Southern blots of rat genomic DNA probed with radio-labelled R1 fragments indicated that the insertion was generated from the $G A B A_{B} R 1$ gene (data not shown). To reveal the precise origin of this new variant $\mathrm{R} 1 \mathrm{c}$ we characterized the complete organization of the $G A B A_{B} R 1$ gene both from $\mathrm{GABA}_{\mathrm{B}} \mathrm{R}$ clones isolated by homology screening of a rat genomic library and by amplifying and sequencing overlapping PCR fragments from genomic DNA. Screening with
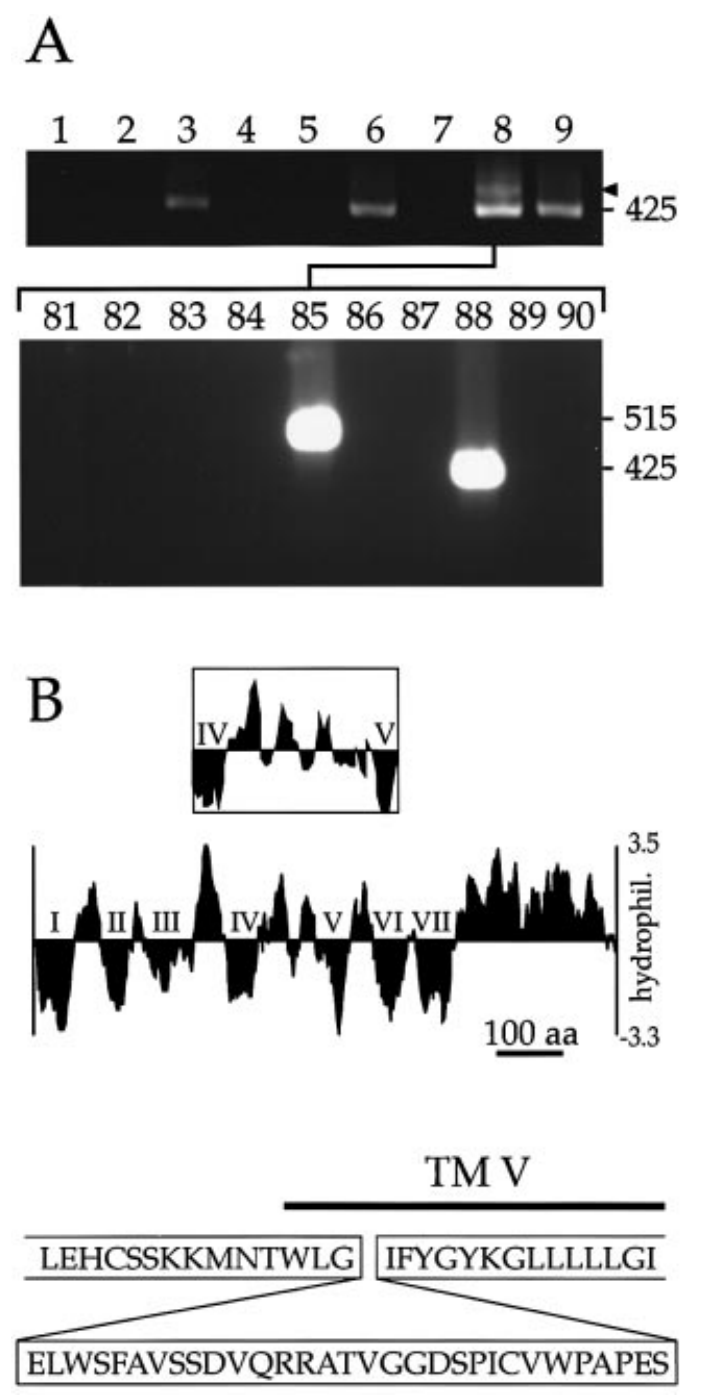

FIG. 1. Identification and localization in the rat $\mathrm{GABA}_{\mathrm{B}} \mathrm{R}$-coding region of a 93$\mathrm{bp}$ insertion. (A) PCR analysis of eight pooled rat hippocampal cDNA sublibraries $\left(\approx 10^{5}\right.$ clones each) with a primer combination designed to amplify a 425-bp fragment from the rat $\mathrm{GABA}_{\mathrm{B}} \mathrm{R}$ (top). Note that in fraction 8 the agarose gel (1.5\%) shows an additional fragment of $520 \mathrm{bp}$ (arrowhead). Analysis of each individual fraction $\left(\approx 10^{4}\right.$ clones each) of sublibrary 8 reveals one of each fragment in subsequent PCR amplifications (bottom). (B) Hydropathy profile of the rat R1b-coding region according to a Kyte and Doolittle algorithm (starting from transmembrane region 1) illustrates the seven $\alpha$-helical transmembrane domains. The insert depicts the equivalent profile of the boxed area for the insertion variant. Shown underneath is the sequence and location of the 31-amino-acid in-frame insertion between the second extracellular region and TM5. 
various radio-labelled DNA probes resulted in the isolation of two R1 clones that covered the complete exonic organization of the gene. Similarly to the mGluRs, the $G A B A_{B} R 1$ gene was interrupted by various introns indicating that exon splicing is an essential step in the processing of $\mathrm{GABA}_{\mathrm{B}} \mathrm{R}$ precursor mRNA (Fig. 2). The structure of the $G A B A_{B} R 1$ gene within the coding region is complex, with 20 exons distributed over $>23 \mathrm{~kb}$. All donor and acceptor sites of the exon-intron boundaries followed the GT-AG rule (BCM Genefinder software at the Human Genome Center, Houston, TX, USA). From genomic data two alternative splicing mechanisms in the $G A B A_{B} R 1$ gene can be explained (Fig. 2A,B). One alternative splicing event generates R1a and R1b. The shorter R1b lacks the first four exons present in R1a and, due to the presence of an alternative splice acceptor site upstream of base 494 (the splice site for R1a), harbors an additional unique 145 bases to complete the open reading frame upstream of exon 5 . The second splicing mechanism involves the 31amino-acid insertion preceding TM5. This fragment originates as a separate splicing cassette from alternative $5^{\prime}$ and $3^{\prime}$ sites within a 567bp intron. The donor and acceptor sites in the genomic sequence exactly match the additional exon-exon transitions in the longer

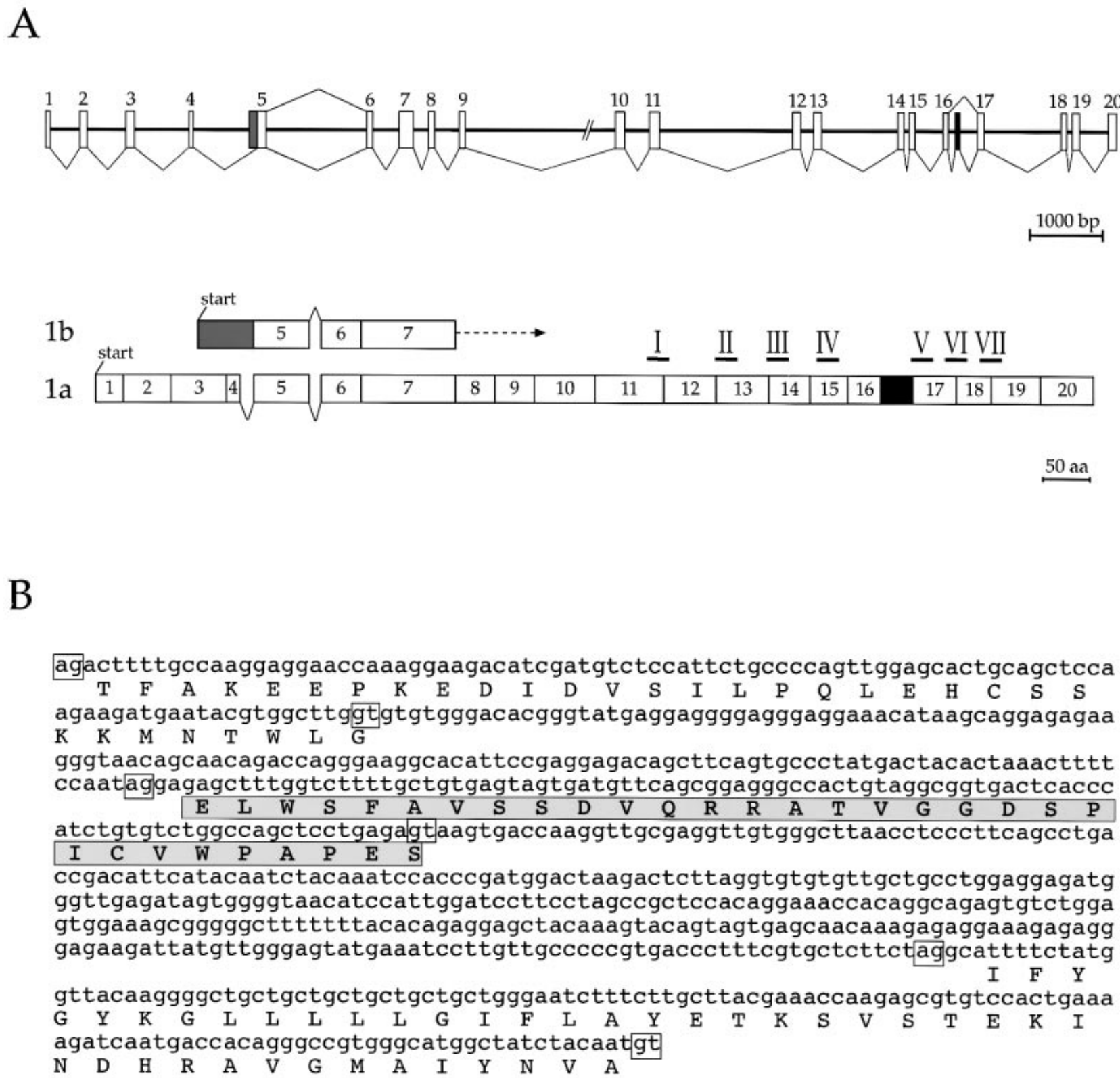

FIG. 2. Genomic organization of the rat $G A B A_{B} R l$ gene. (A) The rat $G A B A_{B} R$ is $>23 \mathrm{~kb}$ in length and contains 20 exons (white and grey boxes) plus an additional

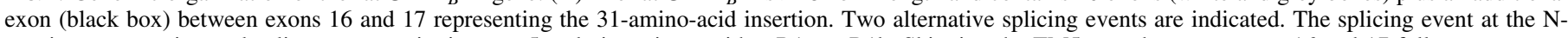

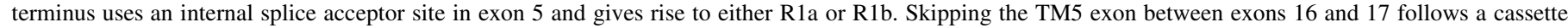

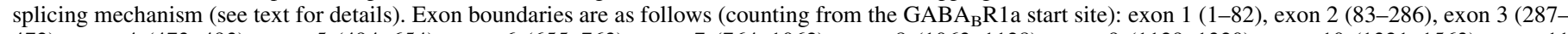

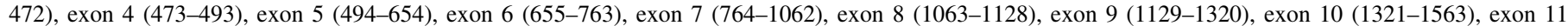
(1564-1705), exon 12 (1706-1856), exon 13 (1857-1989), exon 14 (1990-2106), exon 15 (2107-2214), exon 16 (2215-2308), exon 17 (2309-2436), exon 18

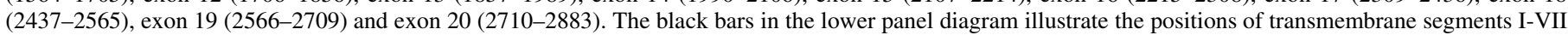

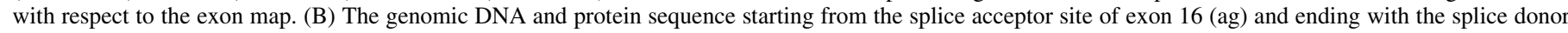

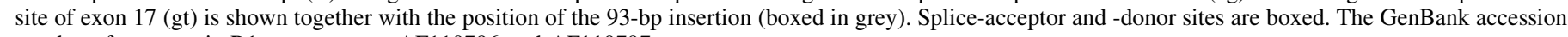
numbers for genomic R1 receptors are AF110796 and AF110797. 

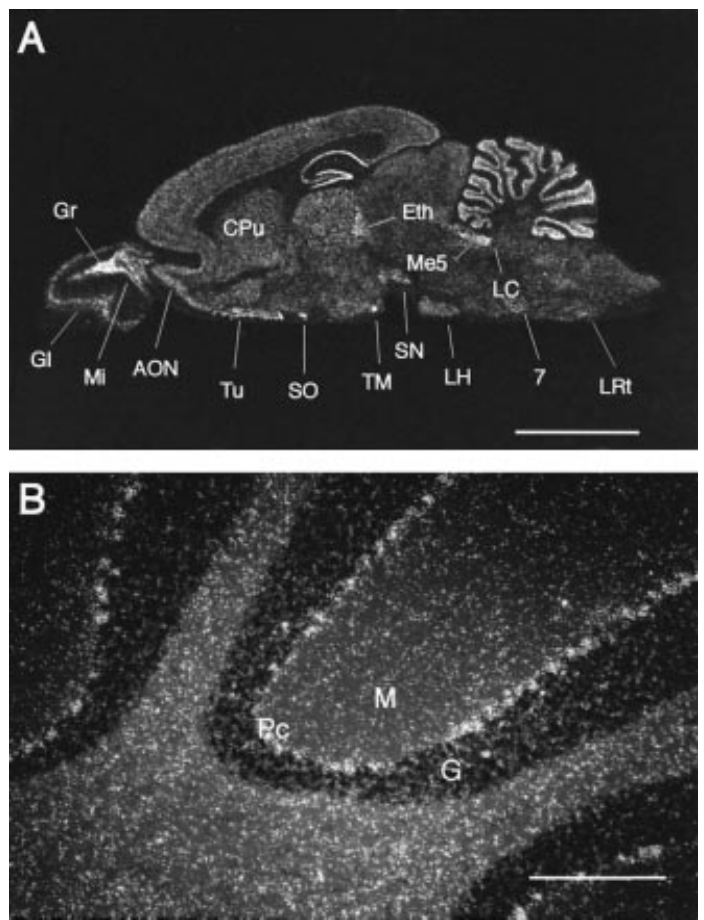

FIG. 3. Localization of the splice variant R1c in the rat brain as revealed by in situ hybridization. Sections were hybridized with a $\left[{ }^{33} \mathrm{P}\right]$-labelled specific oligonucleotide covering 51 bases of the 93-bp insertion as described in Materials and methods. (A) X-ray film autoradiograph of a sagittal section shows R1c mRNA widely distributed in the brain. Bright areas indicate high expression levels. Exposure time was 18 days. 7, facial nucleus; AON, anterior olfactory nucleus; $\mathrm{CPu}$, caudate putamen; Eth, ethmoid thalamic nucleus; $\mathrm{Gl}$, glomerular cell layer; Gr, granule cell layer of the olfactory bulb; LC, locus coeruleus; LH, lateral hypothalamic area; LRt, lateral reticular nucleus; Me5, mesencephalic trigeminal nucleus; $\mathrm{Mi}$, mitral cell layer; $\mathrm{PF}$, parafascicular thalamic nucleus; Pn, pontine nucleus; SN, substantia nigra; SO, supraoptic nucleus; TM, tuberomammillary nucleus; $T u$, olfactory tubercle with islands of Calleja. (B). Dark-field photomicrograph of the cerebellum with strong signals in the Purkinje cells $(P c)$. Scale bars, $5 \mathrm{~mm}(\mathrm{~A})$ and $10 \mu \mathrm{m}(\mathrm{B})$.

receptor transcript. Thus, during processing of $\mathrm{GABA}_{\mathrm{B}} \mathrm{R}$ premRNA, skipping of exon ' $\mathrm{x}$ ' variably causes removal of two smaller introns of 136 and 338 nucleotides instead of the large 567-bp intron, generating two alternatively spliced transcripts. An equivalent analysis using a human PAC clone (12404, Genome Systems, St Louis, MO, USA) indicated that R1c does not exist in man although an intron with moderate sequence homology is situated in the same position (data not shown). In addition to the lack of R1c, the genomic structure of the recently identified human $G A B A_{B} R l$ gene (Peters et al., 1998) deviates at two other sites from the rat gene. Within the 22 exons of the human gene (exons a-d and 1-18), exons 2-4 are combined in rat exons 6-7 and human exons 8-9 are fused to rat exon 11.

To verify the existence and map the localization of the novel R1c transcripts with the 93-bp insertion we performed in situ hybridizations in rat brain sections. We used $\left[{ }^{33} \mathrm{P}\right]$-dATP-end-labelled antisense oligonucleotides covering 51 bases of the TM5 insertion. In general, expression of the alternatively spliced transcript was ubiquitous and expression levels were high in hippocampal CA1 and CA3 pyramidal cell regions and granule cell layers of the dentate gyrus and olfactory tubercle, as well as in the whole cortex and thalamus (Fig. 3A). In the cerebellum, the transcript level was particularly high in Purkinje cells (Fig. 3B) and moderate in the granule cell layer, which agrees with earlier findings of $\mathrm{GABA}_{\mathrm{B}} \mathrm{R}$ radioligand binding sites present on Purkinje cell dendrites and

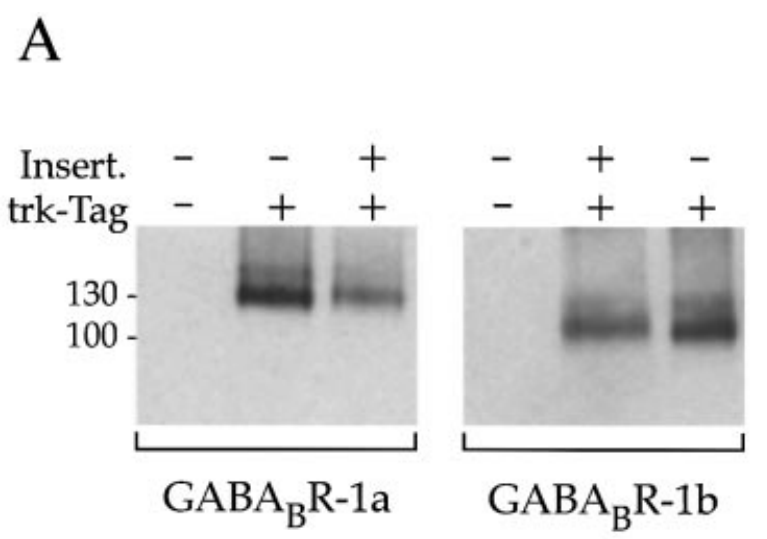

B

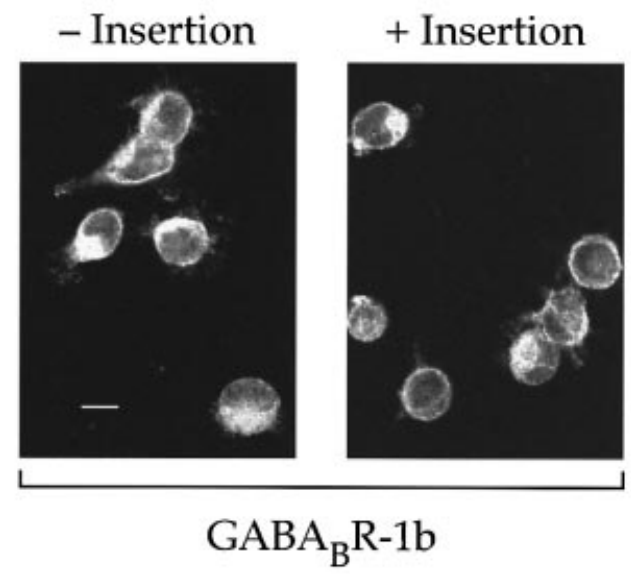

FIG. 4. Immunochemical analysis of $\mathrm{GABA}_{B} \mathrm{R}$ splice variants. (A) Membrane preparations of COS-7 cells expressing R1a and R1b (alternatively epitopetagged with trk) were immunoblotted and analysed with rabbit polyclonal $\alpha$ trk-tag antibodies. The tagged R1a and R1b are detected at $\approx 130$ and $100 \mathrm{~K}$, respectively, independent of the presence or absence of the TM5 insertion. (B) Immunocytochemical localization by confocal fluorescence microscopy of trktagged $\mathrm{GABA}_{\mathrm{B}} \mathrm{R}$ variants in HEK-293 cells. Cells were transiently transfected with pcDNA3 carrying recombinant R1b with (left) or without (right) the TM5-insertion. Antibodies to $\alpha$-trk were detected by Cy3-conjugated goat- $\alpha$ rabbit antibodies. Scale bar, $10 \mu \mathrm{m}$.

granule cell parallel fibers (Wojcik \& Neff, 1984; Chu et al., 1990). The mRNA distribution of R1c matched well the distribution pattern of R1a and R1b transcripts as analysed with a pan probe that does not discriminate splice variants (data not shown). Because the hybridization signals are overlapping and match with the receptor binding sites reported previously (Bowery \& Pratt, 1992; Kaupmann et al., 1997), expression of the different transcripts in the same neuronal populations is likely.

To evaluate the translation of R1c transcripts and determine the localization of expressed receptor proteins, a 14-amino-acid trkA peptide (trk-tag) was attached to the C-terminus. The 93-bp insertion was cloned into epitope-tagged R1a and R1b cDNAs, transfected into COS-7 cells and membrane fractions separated on an SDS gel. On the immunoblot the $\alpha$-trk-tag antibody recognized two protein bands with an $M_{\mathrm{r}}$ of $130 \mathrm{~K}$ for R1a and a smaller $100 \mathrm{~K}$ band for R1b (Fig. 4A) in good agreement with previous data (Kaupmann etal., 1997). Although slightly weaker signals can be detected for receptors carrying the insertion, these data suggest that R1c is correctly expressed.

HEK-293 cells transfected with epitope-tagged $\mathrm{GABA}_{\mathrm{B}} \mathrm{Rs}$, when analysed by conventional light and confocal microscopy, showed a 


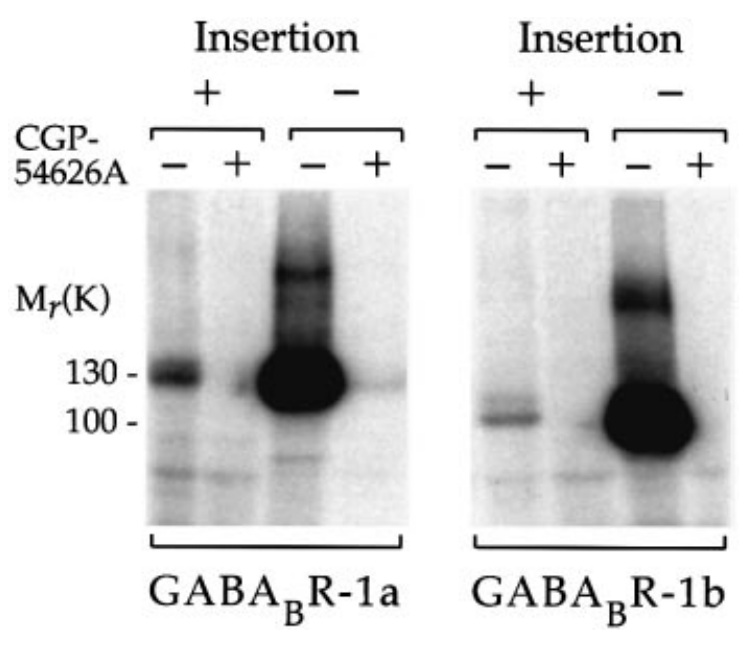

FIG. 5. Photoaffinity labelling of $\mathrm{GABA}_{B} \mathrm{R}$ receptor proteins. Cell membranes from COS-1 cells transfected with R1a and R1b cDNA (with or without the insertion) were photoaffinity-labelled with $\left[{ }^{125} \mathrm{I}\right]$-CGP71872 and subjected to SDS-PAGE (6\%) and autoradiography. $\left[{ }^{125} \mathrm{I}\right]$-CGP71872 binding is inhibited by adding $1 \mu \mathrm{M}$ of the selective antagonist CGP54626 A.

typical punctuate staining both in the cell body and extending into the cellular processes, and did not reveal diffuse staining across the cell as expected for proteins that exclusively reside in the cytosol (Fig. 4B). Strong intracellular staining was also detected in the perinuclear space, e.g. the endoplasmic reticulum and Golgi complex, suggesting protein transport to the outer membrane. No fluorescence signals were detected in nontransfected cells or after transfection with nontagged $\mathrm{GABA}_{\mathrm{B}} \mathrm{Rs}$ (data not shown). It is generally difficult to discriminate intracellular staining from the fluorescence signal on the surface of flat, spread-out cells. To improve detection of edge fluorescence indicative of plasma membrane staining (Makhina \& Nichols, 1998) the transfected cells were mildly trypsinized before analysis (data not shown) or analysed by confocal microscopy. Confocal images indeed demonstrated some edge fluorescence of trktagged R1b with and without the TM5-insertion, suggesting that receptor protein is transported to the outer cell membrane (Fig. 4). In the light of the recent finding that $\mathrm{R} 1$ requires an additional receptor subunit for most efficient plasma membrane targetting (see below; Couve et al., 1998; Kaupmann et al., 1998b), we conclude that when overexpressed in COS-7 cells a fraction of R1 protein (with and without the insertion) may still reach the cell surface.

To characterize the ligand binding capability of the expressed R1c proteins, cell membranes of transiently transfected COS-7 cells were photoaffinity-labelled with $\left[{ }^{125} \mathrm{I}\right] \mathrm{CGP} 71872$ and subjected to SDSPAGE and autoradiography. Weak but significant signals were detected at an $M_{\mathrm{r}}$ of $\approx 130$ and $100 \mathrm{~K}$ for both R1a-TM5 and R1bTM5 and these were completely abolished by addition of $1 \mu \mathrm{M}$ of nonradioactive CGP54626 A (Fig. 5). The weaker signals of R1c (i.e. $\mathrm{R} 1 \mathrm{a}$ or R1b with the TM5 insertion) with respect to R1a and R1b may be indicative of a more inefficient membrane insertion or point to a physiologically relevant receptor subtype with altered pharmacology.

Further evidence that R1c gives rise to functional receptors was provided by their coupling to G-proteins and subsequent activation of inwardly rectifying $\mathrm{K}^{+}$channels in heterologous cells. As demonstrated for human R1a and R1b (Kaupmann etal., 1998b), agonist stimulation of R1c also generated $\mathrm{K}^{+}$inward currents in both COS-7 and tsA201 cells when coexpressed with concatemeric Kir3.1/3.2 or Kir3.1/3.4 subunits (Fig. 6A and B) (Wischmeyer etal., 1997). In COS-7 cells the macroscopic Kir3.1/3.2 current amplitudes elicited by application of $50 \mu \mathrm{M}$ baclofen averaged $-324 \pm 102 \mathrm{pA}(n=13)$ at a holding potential of $-100 \mathrm{mV}$ and with elevated extracellular $\mathrm{K}^{+}$ ( $25 \mathrm{mM}$ ), similar to the values obtained with human R1a (Kaupmann et al., 1998a). The time course of onset of current activation by baclofen and also the relaxation upon removal of the agonist were typically fast, with rate constants between 3 and $6 \mathrm{~Hz}$ (Fig. 6B), suggesting a direct membrane-delimited action of receptor-released Gß $\gamma$ subunits (Hille, 1992; Sodickson \& Bean, 1996). As is known for $\mathrm{GABA}_{\mathrm{B}} \mathrm{Rs}$, when heterologously expressed individually in mammalian cells and Xenopus oocytes, their signalling capabilities are highly inefficient. From 133 tested COS-7 cells that were found cDNAtransfected, based on the presence of prominent Kir3 currents $(>200$ pA at $-100 \mathrm{mV}$ ), only 13 cells, i.e. $9 \%$, responded to baclofen, a value much lower than that found for other GPCRs under the same experimental conditions (e.g. Wischmeyer \& Karschin, 1996). The cause of this deficiency in signalling has now been identified in the requirement of a second $\mathrm{GABA}_{B} \mathrm{R}, \mathrm{R} 2$, which dimerizes with $\mathrm{R} 1$ to provide for efficient signalling in the cellular microenvironment (Jones et al., 1998; Kaupmann et al., 1998b; White et al., 1998; Kuner et al., 1999). Thus, when we injected cRNAs for R1b and R1c (R1bTM5), together with R2, application of $10 \mu \mathrm{M}$ L-baclofen induced robust Kir currents in 12 out of 12 oocytes tested. At a holding potential of $-80 \mathrm{mV}$ and at high external $\mathrm{K}^{+}(96 \mathrm{mM})$, baclofeninduced currents averaged $-3.2 \pm 0.5 \mu \mathrm{A}$ and $-0.52 \pm 0.8 \mu \mathrm{A}$, respectively (Fig. 6C). As revealed by the concentration-response relationship in Fig. 6D, the half-maximal baclofen concentration $\left(\mathrm{EC}_{50}\right)$ was $0.83 \mu \mathrm{M}$ for $\mathrm{R} 1 \mathrm{~b}$ and $2.2 \mu \mathrm{M}$ for $\mathrm{R} 1 \mathrm{c}$, and there was an approximately six-fold lower coupling efficiency of R1c. Supporting these data, similar values were obtained from a second functional assay in which receptors were transfected into HEK-293 cells together with chimeric PLC-activating Goqo subunits (Blahos II et al., 1998). Figure 7 shows that in these cells expressing the indicated $\mathrm{R} 1$ receptor together with R2 and the chimeric G-protein, increasing concentrations of GABA elevated IP levels after a 30-min incubation. Such a response was completely antagonized by the specific antagonist CGP54626 A and was not observed in cells expressing any $\mathrm{GABA}_{\mathrm{B}} \mathrm{R}$ subunit alone (data not shown). The maximal increase in IP production obtained with $1 \mathrm{~mm}$ GABA was similar in cells expressing R1a or R1b. It was, however, approximately five-fold lower in cells expressing R1c (R1aTM5 or R1b-TM5). The $\mathrm{EC}_{50}$ values obtained using this assay were $0.99 \pm 0.01 \mu \mathrm{M}$ and $0.96 \pm 0.05 \mu \mathrm{M}$ for $\mathrm{R} 1 \mathrm{a}$ and $\mathrm{R} 1 \mathrm{~b}$, respectively, and $1.54 \pm 0.1 \mu \mathrm{M}$ and $4.0 \pm 1.24 \mu \mathrm{M}$ for R1a-TM5 and R1b-TM5, respectively $(n=3)$.

\section{Discussion}

The alternative splicing event involving exons 16 and 17 results in a novel $\mathrm{GABA}_{\mathrm{B}} \mathrm{R}$ isoform in rat that carries a 31-amino-acid insertion in the region between the second extracellular loop and the fifth putative transmembrane segment. In other small-ligand GPCRs this region may be part of the ligand binding domain (van Rhee \& Jacobson, 1996). In contrast, in the metabotropic GABA and glutamate receptors the large-size $\mathrm{N}$-terminal extracellular domain is primarily responsible for agonist binding (Okamoto et al., 1998). Except for a potential phosphorylation site for protein kinase A and the presence of a cysteine residue that may form disulphide bonds with other extracellularly located cysteines, the primary sequence of the insertion does not exhibit significant similarity to other proteins. On the other hand, the genomic organization, the wide mRNA distribution in the brain and the proper translation into functional membrane protein are consistent with R1c transcripts yielding physiologically relevant $\mathrm{GABA}_{\mathrm{B}}$ receptors. 
A

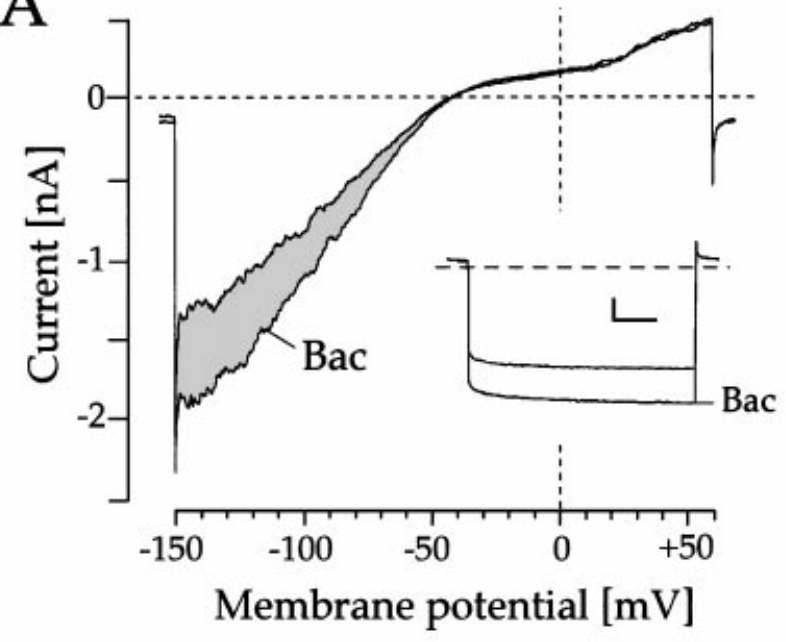

B

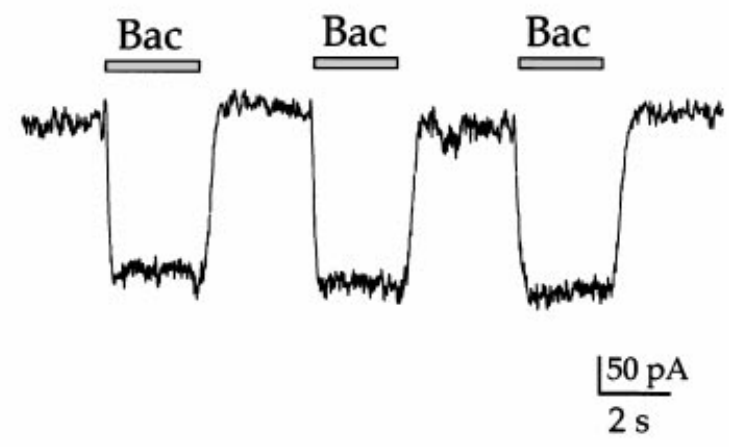

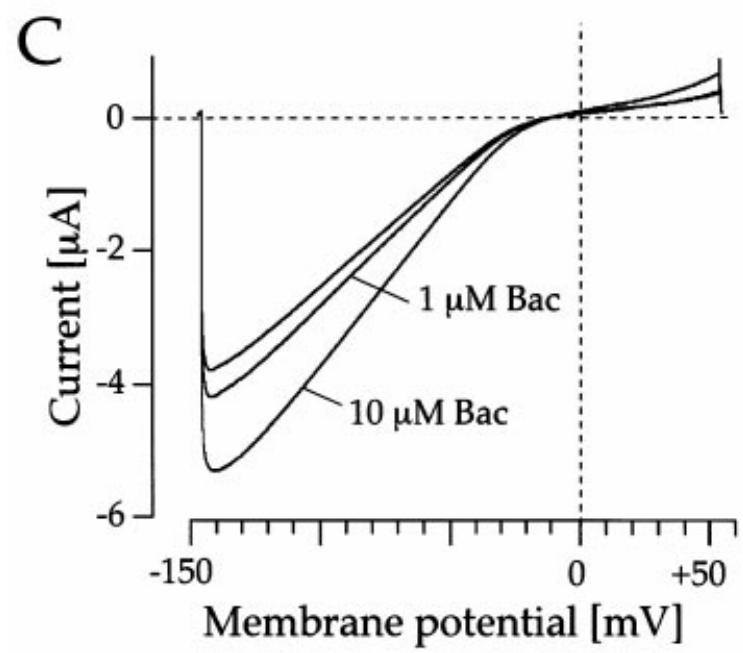

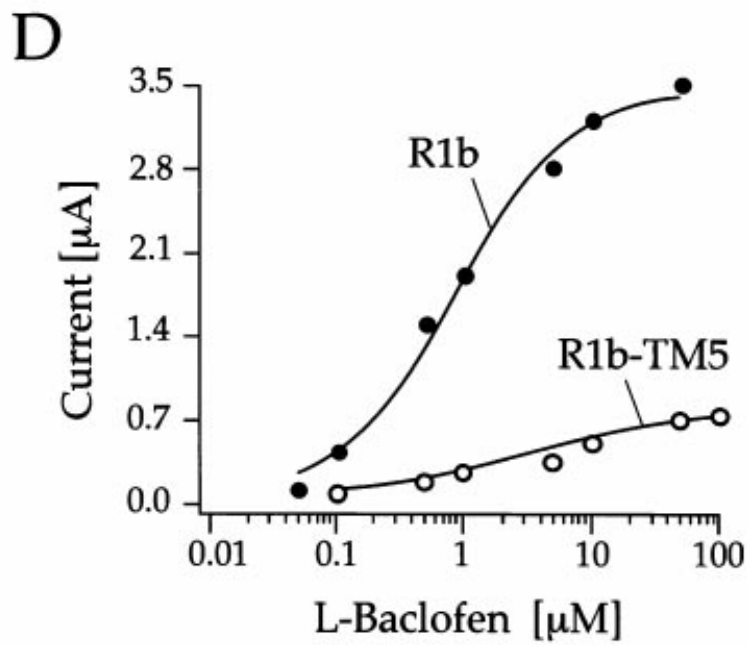

FIG. 6. R1c couples to activation of G-protein-coupled Kir3 channels. (A) Ramp currents of COS-7 cells cotransfected with R1c and concatenated Kir3.1/3.2 cDNA in response to $500-\mathrm{ms}$ voltage ramps between $-150 \mathrm{mV}$ and $+60 \mathrm{mV}$ show inward rectification of baclofen-induced responses $(50 \mu \mathrm{M})$. The inset displays currents in reponse to $500-\mathrm{ms}$ voltage pulses to $-120 \mathrm{mV}$ from a holding potential of $-60 \mathrm{mV}$ in the presence and absence of the agonist. Scale bars, $0.1 \mathrm{~s}$ and $300 \mathrm{pA}$. (B) Whole cell currents at a holding potential of $-120 \mathrm{mV}$ in the presence and absence of $50 \mu \mathrm{M}$ baclofen applied through a fast microperfusion system (solution changes in $<20 \mathrm{~ms}$ ). The extracellular concentration of $\mathrm{K}^{+}$in A and B is $25 \mathrm{~mm}$. (C) Representative ramp responses in Xenopus oocytes injected with R1c, R2 and Kir3.1/3.2 cRNAs. Responses are receptor-activated Kir currents in $96 \mathrm{mM} \mathrm{K}^{+}$at $-80 \mathrm{mV}$ after application of baclofen as indicated. (D) Concentration-response relationship of R1b (black dots) and R1c (R1b-TM5; open circles) for L-baclofen. Curves are least-squares fits of data points to a Michaelis-Menten equation $\left\{I=I_{\max }\left(A^{n} / A^{n}+\mathrm{EC}_{50}\right)\right\}$, where $A$ is the agonist concentration, $\mathrm{EC}_{50}$ the half-maximal agonist concentration and $n$ a variable coefficient. The $\mathrm{EC}_{50}$ is $0.83 \mu \mathrm{M}$ for $\mathrm{R} 1 \mathrm{~b}$ and $2.2 \mu \mathrm{M}$ for R1c (R1b-TM5).

Although functional diversity in GPCRs mainly results from gene duplication, and most lack intronic sequences, several GPCR isoforms generated by alternative splicing have now been reported. Some splicing events generate shorter proteins and thus change receptor function. The metabotropic glutamate receptors mGluR1 and mGluR5 (Pin etal., 1992; Tanabe etal., 1992; Joly et al., 1995), the prostanoid EP3 (Namba etal., 1993), the TXA2 receptor (Raychowdhury et al., 1994), and vasopressin V2 receptor (Firsov et al., 1994), for example, are alternatively spliced in their C-terminal regions, generating transcripts with unique distribution patterns and G-protein-coupling characteristics (Pickering etal., 1993). Two alternative splice products of the dopamine D2 receptor, D2 $\mathrm{L}$ and D2 $2_{S}$ (Dal Toso et al., 1989; Monsma et al., 1989) selectively couple to different G-protein isoforms (Blahos II et al., 1998). This functional consequence was to be expected since these two isoforms are being created by a 29-amino-acid insertion into the third intracellular loop which is a known determinant of G-protein binding. In contrast, shorter insertions at other intracellular sites of $\mathrm{D} 2 \mathrm{~L}$ or mGluR5a receptors have not been found to affect coupling to signalling pathways significantly.

No significant difference was found between the transcript distribution patterns of $\mathrm{R} 1 \mathrm{a}, \mathrm{R} 1 \mathrm{~b}$ and $\mathrm{R} 1 \mathrm{c}$ that virtually coincided with receptor binding profiles. Since both R1a and R1b subtypes have been found to variably contain the TM5-insertion, CNS neurons probably coexpress all splice variants in pre- and postsynaptic cellular structures. Earlier reports have collected strong evidence that $\mathrm{GABA}_{\mathrm{B}}$ receptors are located both pre- and postsynaptically and Koulen etal. (1998) demonstrated that R1a and R1b protein in rat retinal neurons is localized on either side of the synapse. To date no specific agonists or antagonists have been described that clearly 


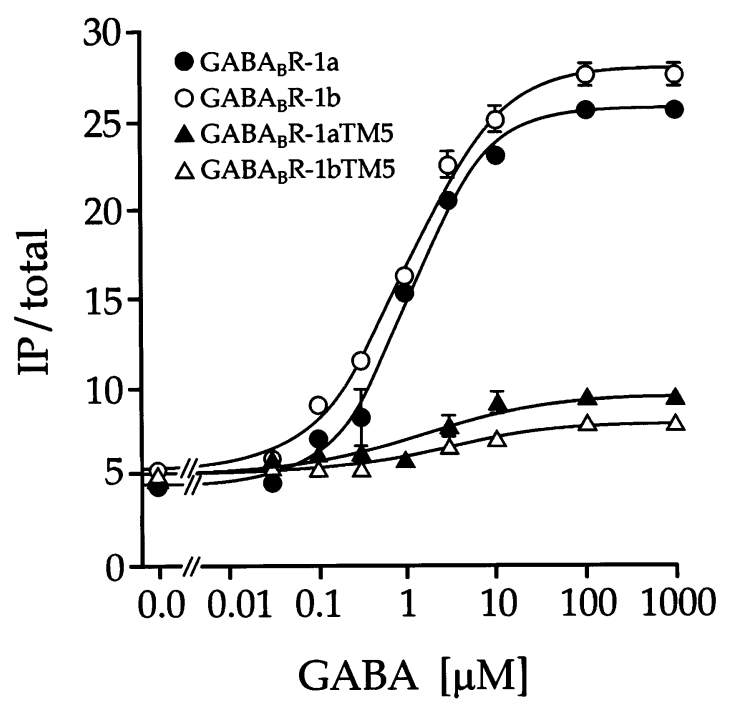

FIG. 7. Functional coupling of $\mathrm{GABA}_{\mathrm{B}} \mathrm{Rs}$ to IP formation via recombinant chimeric Goqo proteins. HEK-293 cells prelabelled with $\left[{ }^{3} \mathrm{H}\right]-$ myo-inositol and transiently expressing the chimeric Goqo proteins, the R2 and the R1 isoforms were stimulated with the indicated concentrations for GABA in the presence of $10 \mathrm{mM} \mathrm{LiCl}$ and subsequently the total IP formation was determined. Results are means ( \pm SEM) of triplicate determinations from a typical experiment.

distinguish between receptors on pre- and postsynaptic sites and thus it is unclear whether their molecular nature is unique. Presynaptically, $\mathrm{GABA}_{\mathrm{B}} \mathrm{Rs}$ have been found on terminals that release GABA (autoreceptors) or other neurotransmitters (heteroreceptors; Bonanno \& Raiteri, 1993; Kerr \& Ong, 1995) and in most cases are inhibitory to voltage-sensitive $\mathrm{Ca}^{2+}$ channels. Ligand binding to postsynaptic $\mathrm{GABA}_{\mathrm{B}}$ receptors causes inhibition of adenylate cyclase via the $\alpha$ subunits of pertussis-toxin-sensitive $\mathrm{G}_{\mathrm{i} / \mathrm{o}}$ proteins (Wojcik \& Neff, 1984). Following the same stimulus, liberated G $\beta \gamma$ subunits rapidly activate Kir channels, probably in a membrane-delimited manner, and hyperpolarize the postsynaptic membrane (Newberry \& Nicoll, 1984). Both activation of heteromeric Kir3 channels and increase of endogenous cAMP levels upon baclofen stimulation were achieved following injection of brain poly $(\mathrm{A})^{+}$RNA into Xenopus oocytes (Uezono et al., 1997, 1998). Although in rare cases we managed to reconstitute direct activation of Kir3 channels by recombinant R1a and R1b in mammalian cells (Kaupmann etal., 1998a), reliable functional expression of $\mathrm{GABA}_{\mathrm{B}} \mathrm{Rs}$ in oocytes has only recently been obtained. These observations had suggested earlier that cell-specific modification of the receptors or even another membrane protein are crucial for a more efficient membrane targetting of the receptors and their assembly into G-protein-mediated signalling cascades. Candidate proteins may be related to 'receptor-activity-modifying proteins' (RAMPs; McLatchie etal., 1998), transducisomes (Tsunoda etal., 1997) or other anchoring and adaptor proteins (Pawson \& Scott, 1997) for which a regulatory role in receptor expression has been shown. Only very recently evidence was provided, however, that the primary cause of this shortcoming was the preferential dimeric assembly of R1a and R1b with a newly identified $\mathrm{GABA}_{\mathrm{B}} \mathrm{R}$ subtype, GABA $_{B}$ R2 (Jones et al., 1998; Kaupmann et al., 1998b; White et al., 1998; Kuner etal., 1999). The formation of functional heteromeric receptor complexes greatly improves G-protein coupling in the heterologous system and also partially helps to explain the observed severe discrepancy in agonist binding activities $(\approx 100$-fold) between recombinant $\mathrm{R} 1$ and native $\mathrm{GABA}_{\mathrm{B}} \mathrm{R}$ in the brain. The $\mathrm{EC}_{50}$ of $\approx 1 \mu \mathrm{M}$ reported in this study for the $\mathrm{R} 1 \mathrm{~b} / \mathrm{R} 2$ combination in oocytes is only approximately five-fold higher than for native receptors in rat cerebral cortex (Kaupmann etal., 1997). The successful functional coupling of dimeric receptors to both Kir3.1/3.2 channels and PLCactivating chimeric Goqo protein also shows that agonist potency of $\mathrm{R} 1 \mathrm{c}$ under our conditions is in a similar range to that of $\mathrm{R} 1 \mathrm{a}$ and $\mathrm{R} 1 \mathrm{~b}$ and that $\mathrm{R} 1 \mathrm{c}$ is therefore unlikely to form a molecularly unique highor low-affinity $\mathrm{GABA}_{\mathrm{B}} \mathrm{R}$. The weaker R1c signals in [ $\left.{ }^{125} \mathrm{I}\right] \mathrm{CGP} 71872$ photoaffinity labelling and the five- to six-fold lower signalling efficacy may be indicative of lower expression levels of functional protein in both HEK-293 cells and Xenopus oocytes. The functional roles $\mathrm{R} 1 \mathrm{c}$ may play in the mammalian CNS remain elusive.

\section{Acknowledgements}

We are grateful to Drs E. Wischmeyer and J. Mosbacher for advice and supplementary data on the oocyte voltage-clamp experiments, Dr C. Karschin for help with the in situ hybridizations, as well as G. Dowe, D. Reuter and S. Voigt for excellent technical assistance. We also thank Dr C. Rosenmund for providing the hippocampal cell cultures. This work was supported in part by the Deutsche Forschungsgemeinschaft (SFB 406).

\section{Abbreviations}

GABA, $\gamma$-aminobutyric acid; $\mathrm{GABA}_{\mathrm{B}} \mathrm{R}$, metabotropic $\mathrm{GABA}_{\mathrm{B}}$ receptor; GPCR, G-protein-coupled receptor; IP, inositol phosphates; Kir, inwardly rectifying $\mathrm{K}^{+}$channel; mGluR, metabotropic glutamate receptor; R1a, $\mathrm{GABA}_{\mathrm{B}} \mathrm{R}$ type $1 \mathrm{a} ; \mathrm{R} 1 \mathrm{~b}, \mathrm{GABA}_{\mathrm{B}} \mathrm{R}$ type $1 \mathrm{~b} ; \mathrm{R} 1 \mathrm{c}, \mathrm{GABA}_{\mathrm{B}} \mathrm{R}$ type $1 \mathrm{c}$ TM5splice variant; $\mathrm{R} 2, \mathrm{GABA}_{\mathrm{B}} \mathrm{R}$ type $2 ; \mathrm{TM}$, transmembrane region.

\section{References}

Bettler, B., Kaupmann, K. \& Bowery, N. (1998) GABA B $_{\text {B }}$ receptors: drugs meet clones. Curr. Opin. Neurobiol., 8, 345-350.

Blahos II, J., Mary, S., Perroy, J., de Colle, C., Brabet, I., Bockaert, J. \& Pin, J.P. (1998) Extreme $C$ terminus of $G$ protein $\alpha$-subunits contains a site that discriminates between Gi-coupled metabotropic glutamate receptors. $J$. Biol. Chem., 273, 25765-25769.

Bonanno, G. \& Raiteri, M. (1993) Gamma-aminobutyric acid (GABA) autoreceptors in rat cerebral cortex and spinal cord represent pharmacologically distinct subtypes of the $\mathrm{GABA}_{\mathrm{B}}$ receptor. $J$. Pharmacol. Exp. Ther., 265, 765-770.

Bowery, N.G. \& Brown, D.A. (1997) The cloning of $\mathrm{GABA}_{B}$ receptors. Nature, 386, 223-224.

Bowery, N.G. \& Pratt, G.D. (1992) $\mathrm{GABA}_{\mathrm{B}}$ receptors as targets for drug action. Arzneim. Forsch., 42, 215-223.

Brown, E.M., Gamba, G., Riccardi, D., Lombardi, M., Butters, R., Kifor, O., Sun, A., Hediger, M.A., Lytton, J. \& Hebert, S.C. (1993) Cloning and characterization of an extracellular $\mathrm{Ca}^{2+}$-sensing receptor from bovine parathyroid. Nature, 366, 575-580.

Chu, D.C., Albin, R.L., Young, A.B. \& Penney, J.B. (1990) Distribution and kinetics of $\mathrm{GABA}_{\mathrm{B}}$ binding sites in rat central nervous system: a quantitative autoradiographic study. Neuroscience, 34, 341-357.

Couve, A., Filippov, A.K., Connolly, C.N., Bettler, B., Brown, D.A. \& Moss, S.J. (1998) Intracellular retention of recombinant $\mathrm{GABA}_{\mathrm{B}}$ receptors. J. Biol. Chem., 273, 26361-26367.

Cunningham, M.D. \& Enna, S.J. (1996) Evidence for pharmacologically distinct $\mathrm{GABA}_{\mathrm{B}}$ receptors associated with cAMP production in rat brain. Brain Res., 720, 220-224.

Dal Toso, R., Sommer, B., Ewert, M., Herb, A., Pritchett, D.B., Bach, A., Shivers, B.D. \& Seeburg, P.H. (1989) The dopamine $\mathrm{D}_{2}$ receptor: two molecular forms generated by alternative splicing. EMBO J., 8, 4025-4034.

Firsov, D., Mandon, B., Morel, A., Merot, J., Le Maout, S., Bellanger, A.C., de Rouffignac, C., Elalouf, J.M. \& Buhler, J.M. (1994) Molecular analysis of vasopressin receptors in the rat nephron. Evidence for alternative splicing of the V2 receptor. Pfiügers Arch., 429, 79-89.

Guiramand, J., Montmayeur, J.P., Ceraline, J., Bhatia, M. \& Borrelli, E. (1995) Alternative splicing of the dopamine D2 receptor directs specificity of coupling to G-proteins. J. Biol. Chem., 270, 7354-7358.

Hille, B. (1992) G protein-coupled mechanisms and nervous signaling. Neuron, 9, 187-195.

Isomoto, S., Kaibara, M., Sakurai-Yamashita, Y., Nagayama, Y., Uezono, Y., 
Yano, K. \& Taniyama, K. (1998) Cloning and tissue distribution of novel splice variants of the rat $\mathrm{GABA}_{\mathrm{B}}$ receptor. Biochem. Biophys. Res. Com., 253, 10-15.

Johnston, G.A.R. (1996) GABA $_{C}$ receptors: relatively simple transmitter-gated ion channels? Trends Pharmacol. Sci., 17, 319-323.

Joly, C., Gomeza, J., Brabet, I., Curry, K., Bockaert, J. \& Pin, J.P. (1995) Molecular, functional, and pharmacological characterization of the metabotropic glutamate receptor type 5 splice variants: Comparison with mGluR1. J. Neurosci., 15, 3970-3981.

Jones, K.A., Borowsky, B., Tamm, J.A., Craig, D.A., Durkin, M.M., Dai, M., Yao, W.-J., Johnson, M., Gunwaldsen, C., Huang, L.-Y., Tang, C., Shen, Q., Salon, J.A., Morse, K., Laz, T., Smith, K.E., Nagarathnam, D., Noble, S.A., Branchek, T.A. \& Gerald, C. (1998) GABA $_{B}$ receptors function as a heteromeric assembly of the subunits $\mathrm{GABA}_{\mathrm{B}} \mathrm{R} 1$ and $\mathrm{GABA}_{\mathrm{B}} \mathrm{R} 2$. Nature, 396, 674-769.

Karschin, C., Dissmann, E., Stühmer, W. \& Karschin, A. (1996) IRK (1-3) and GIRK (1-4) inwardly rectifying $\mathrm{K}^{+}$channel mRNAs are differentially expressed in the adult rat brain. J. Neurosci., 16, 3559-3570.

Kaupmann, K., Huggel, K., Heid, J., Flor, P.J., Bischoff, S., Mickel, S.J., McMaster, G., Angst, C., Bittiger, H., Froestl, W. \& Bettler, B. (1997) Expression cloning of $\mathrm{GABA}_{\mathrm{B}}$ receptors uncovers similarity to metabotropic glutamate receptors. Nature, 386, 239-246.

Kaupmann, K., Malitschek, B., Schuler, V., Heid, J., Froestl, W., Beck, P., Mosbacher, J., Bischoff, S., Kulik, A., Shigemoto, R., Karschin, A. \& Bettler, B. (1998b) GABA $_{\mathrm{B}}$-receptor subtypes assemble into functional heteromeric complexes. Nature, in press.

Kaupmann, K., Schuler, V., Mosbacher, J., Bischoff, S., Bittiger, H., Heid, J., Fröstl, W., Leonhardt, T., Pfaff, T., Karschin, A. \& Bettler, B. (1998a) Human $\mathrm{GABA}_{\mathrm{B}}$ receptors are differentially expressed and regulate inwardly rectifying $\mathrm{K}^{+}$channels. Proc. Natl Acad. Sci. USA, 95, 14991-14996.

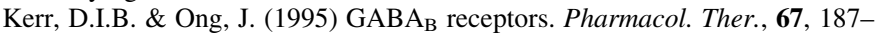
246.

Koulen, P., Malitschek, B., Kuhn, R., Bettler, B., Wässle, H. \& Brandstätter, J.H. (1998) Presynaptic and postsynaptic localization of GABA (B) receptors in neurons of the rat retina. Eur. J. Neurosci., 10, 1446-1456.

Kuner, R., Köhr, G., Grünewald, S., Eisenhardt, G., Bach, A. \& Kornau, H.-C. (1999) Role of Heteromer Formation in GABA $_{B}$ Receptor Function. Science, 283, 74-77.

Makhina, E.N. \& Nichols, C.G. (1998) Independent trafficking of $\mathrm{K}_{\mathrm{ATP}}$ channel subunits to the plasma membrane. J. Biol. Chem., 273, 3369-3374.

Matsunami, H. \& Buck; L.B. (1997) A multigene family encoding a diverse array of putative pheromone receptors in mammals. Cell, 90, 775-784.

McLatchie, L.M., Fraser, N.J., Main, M.J., Wise, A., Brown, J., Thompson, N., Solari, R., Lee, M.G. \& Foord, S.M. (1998) RAMPs regulate the transport and ligand specificity of the calcitonin-receptor-like receptor. Nature, 393, 333-339.

Monsma,F.J., JrMcVittie, L.D., Gerfen, C.R., Mahan, L.C. \& Sibley, D.R. (1989) Multiple $\mathrm{D}_{2}$ dopamine receptors produced by alternative RNA splicing. Nature, 342, 926-929.

Nakanishi, S. (1994) Metabotropic glutamate receptors: Synaptic transmission, modulation, and plasticity. Neuron, 13, 1031-1037.

Namba, T., Sugimoto, Y., Negishi, M., Irie, A., Ushikubi, F., Kakizuka, A., Ito, S., Ichikawa, A. \& Narumiya, S. (1993) Alternative splicing of Cterminal tail of prostaglandin E receptor subtype EP3 determines G-protein specificity. Nature, 365, 166-169.

Newberry, N.R. \& Nicoll, R.A. (1984) Direct hyperpolarizing action of baclofen on hippocampal pyramidal cells. Nature, 308, 450-452.

Okamoto, T., Sekiyama, N., Otsu, M., Shimada, Y., Sato, A., Nakanishi, S. \& Jingami, H. (1998) Expression and purification of the extracellular ligand binding region of metabotropic glutamate receptor subtype 1. J. Biol. Chem., 273, 13089-13096.

Pawson, T. \& Scott, J.D. (1997) Signaling Through Scaffold, Anchoring and Adaptor Proteins. Science, 278, 2075-2080.

Peters, H.C., Kämmer, G., Volz, A., Kaupmann, K., Ziegler, A., Bettler, B.,
Epplen, J.T., Sander, T. \& Riess, O. (1998) Mapping, genomic structure, and polymorphisms of the human $\mathrm{GABA}_{\mathrm{B}} \mathrm{R} 1$ receptor gene: evaluation of its involvement in idiopathic generalized epilepsy. Neurogenetics, 2, 47-58.

Pfaff, T. \& Karschin, A. (1997) Expression cloning of rat cerebellar adenosine A1 receptor by coupling to Kir channels. Neuroreport, 8, 2455-2460.

Pickering, D.S., Thomsen, C., Suzdak, P.D., Fletcher, E.J., Robitaille, R., Salter, M.W., MacDonald, J.F., Huang, X.P. \& Hampson, D.R. (1993) A comparison of two alternatively spliced forms of a metabotropic glutamate receptor coupled to phosphoinositide turnover. J. Neurochem., 61, 85-92.

Pin, J.P. \& Duvoisin, R. (1995) Review: Neurotransmitter receptors I. The metabotropic glutamate receptors: Structure and functions. Neuropharmacology, 34, 1-26.

Pin, J.P., Waeber, C., Prezeau, L., Bockaert, J. \& Heinemann, S.F. (1992) Alternative splicing generates metabotropic glutamate receptors inducing different patterns of calcium release in Xenopus oocytes. Proc. Natl Acad. Sci. USA, 89, 10331-10335.

Raychowdhury, M.K., Yukawa, M., Collins, L.J., McGrail, S.H., Kent, K.C. \& Ware, J.A. (1994) Alternative splicing produces a divergent cytoplasmic tail in the human endothelial thromboxane A2 receptor J. Biol. Chem., 269, 19256-19261.

van Rhee, A.M. \& Jacobson, K.A. (1996) Molecular architecture of G proteincoupled receptors. Drug Dev. Res., 37, 1-38.

Schofield, P.R., Darlison, M.G., Fujita, N., Burt, D.R., Stephensen, F.A., Rodriguez, H., Rhee, L.M., Ramachandran, J., Reale, V., Glencorse, T.A., Seeburg, P. \& Barnard, E.A. (1987) Sequence and functional expression of the $\mathrm{GABA}_{\mathrm{A}}$ receptor shows a ligand-gated receptor super-family. Nature, 328, 221-227.

Sodickson, D.L. \& Bean, B.P. (1996) GABA $_{B}$ receptor-activated inwardly rectifying potassium current in dissociated hippocampal CA3 neurons. $J$. Neurosci., 16, 6374-6385.

Tanabe, Y., Masu, M., Ishii, T., Shigemoto, R. \& Nakanishi, S. (1992) A family of metabotropic glutamate receptors. Neuron, 8, 169-179.

Tsunoda, S., Sierralta, J., Sun, Y., Bodner, R., Suzuki, E., Becker, A., Socolich, M. \& Zuker, C.S. (1997) A multivalent PDZ-domain protein assembles signaling complexes in a G-protein-coupled cascade. Nature, 388, 243-249.

Uezono, Y., Akihara, M., Kaibara, M., Kawano, C., Shibuya, I., Ueda, Y., Yanagihara, N., Toyohira, Y., Yamashita, H., Taniyama, K. \& Izumi, F. (1998) Activation of inwardly rectifying $\mathrm{K}^{+}$channels by GABA-B receptors expressed in Xenopus oocytes. Neuroreport, 9, 583-587.

Uezono, Y., Ueda, Y., Ueno, S., Shibuya, I., Yanagihara, N., Toyohira, Y., Yamashita, H. \& Izumi, F. (1997) Enhancement by baclofen of the Gscoupled receptor-mediated cAMP production in Xenopus oocytes expressing rat brain cortex poly (A) ${ }^{+}$RNA: a role of $G$ protein $\beta \gamma$ subunits. Biochem. Biophys. Res. Com., 241, 476-480.

White, J.H., Wise, A., Main, M.J., Green, A., Fraser, N.J., Disney, G.H., Barnes, A.A., Emson, P., Foord, S.M. \& Marshall, F.H. (1998) Heterodimerization is required for the formation of a functional GABA $_{B}$ receptor. Nature, 396, 679-682.

Wischmeyer, E., Döring, F., Wischmeyer, E., Spauschus, A., Thomzig, A., Veh, R. \& Karschin, A. (1997) Subunit interactions in the assembly of neuronal Kir3.0 inwardly rectifying $\mathrm{K}^{+}$channels. Mol. Cell. Neurosci., 9, 194-206.

Wischmeyer, E. \& Karschin, A. (1996) Receptor stimulation causes slow inhibition of IRK1 inwardly rectifying $\mathrm{K}^{+}$channels by direct protein kinase A-mediated phosphorylation. Proc. Natl Acad. Sci. USA, 93, 5819-5823.

Wojcik, W.J., Travagli, R.A., Costa, E. \& Bertolino, M. (1990) Baclofen inhibits with high affinity an L-type-like voltage-dependent calcium channel in cerebellar granule cell cultures. Neuropharmacology, 29, 969-972.

Wojcik, W.J. \& Neff, N.H. (1984) $\gamma$-aminobutyric acid B receptors are negatively coupled to adenylate cyclase in brain, and in the cerebellum these receptors may be associated with granule cells. Mol. Pharmacol., 25, 24-28. 